\title{
The Influence of the Internal Environment on the Empowerment of MSMEs Based on Environmental Management
}

\section{Rita Syntia', Badaruddin², Isfenti Sadalia², and Miswar Budi Mulya²}

${ }^{1}$ Doctoral Study Program of Natural Resource Management and Environment, Universitas Sumatera Utara, Medan, Indonesia

${ }^{2}$ Graduate School Courses of Natural Resources Management and Environment, Universitas Sumatera Utara, Medan, Indonesia

\section{Abstract}

The purpose of this research is to figure out how the internal environment influences the empowerment of MSMEs based on environmental management in the district of Aceh Tamiang. Research Population is 965 MSMEs in the district of Aceh Tamiang. The selected sample is 300 business practitioners in accordance to a sample fit

Corresponding Author: Rita Syntia ritasyntia36@gmail.com

Received: 29 August 2018 Accepted: 18 September 2018 Published: 11 November 2018 Publishing services provided by Knowledge $\mathrm{E}$

(c) Rita Syntia et al. This article is distributed under the terms of the Creative Commons

Attribution License, which permits unrestricted use and redistribution provided that the original author and source are credited.

Selection and Peer-review under the responsibility of the ICOI-2018 Conference Committee.

\section{G OPEN ACCESS} for structural equation modeling test. Data analysis was done using descriptive statistics with SPSS analysis and Structural Equation Modeling (SEM) with AMOS. The research results showed that internal environmental factors significantly affect the empowerment of MSMEs based on environmental management and support the creation of 'environment-friendly business'.

Keywords: internal environment, go green, environmental management, Industrial Micro Small And Medium Enterprises (MSMEs)

\section{Introduction}

Indonesia is one of the countries that make the program development of micro small and medium-sized businesses becomes one of the primary implementer of economic growth. One of the characteristics of the dynamics and good economic performance with the level of high growth in the countries of East and South East Asia such as South Korea, Singapore, and Taiwan is the performance of micro small and mediumsized businesses that are very efficient, productive and have high competitiveness. Small and medium-sized businesses in Indonesia play an important role to enhance economic growth and give additional value to reduce poverty and increase prosperity. Employment in 2012 has reached 14 million people with micro small and mediumsized business industries, workers are able to contribute $12-13 \%$ from throughout the number of national labor. (Indris and Primiana, 2015) 
The growth of small and medium-sized businesses is not accompanied by the increasement of knowledge and awareness to keep the environment. Business doers do not have the knowledge and skills in managing the business applying the environmental management which causes an impact on the development of business with intention of conserving the nature (Moorthy \& Arokiasamy, 2012). Business doers have no knowledge regarding the benefits of business sustainability if the business management based on environmental management. Indonesia has become one of the countries which business have limited or lack of knowledge regarding the concept of green business. Meanwhile, the government has started to hold seminar, education and empowerment program focusing on environmental and industrial friendly. (Bank Indonesia, 2012). Numerous efforts have been made in the world through NGOS that understand sustainable development as a strategy of anti-industry and anti-modernist adequacy, restrict themselves to fulfill the needs, withdraw from free market economy and stop the distribution of scarce resources. Contrary to the understanding, that the sustainable development is in fact an efficiency revolution. Business and industry are looking for a strategy that supports the development of sustainable economic growth and ecological adaptation of industrial production at the same time. The means to achieve the goal was done through the introduction of environmental management systems in improving environmental performance by increasing the efficiency of materials usage and energy impact with the purpose of achieving the maximum productivity of resources in addition to the productivity of labor and capital.

Some problems for the sustainability of the small business environmental friendly is capital and knowledge limitations as well as the understanding of human resources, readiness of small businesses in running the environmental friendly business activities, supporting facilities and infrastructure business activities which are not in accordance to the limitations of technology to achieve the innovation, Demographic factors such as age, education, income do not support this because they do not understand the concept of business. (Bank Indonesia, 2012; Indarti \& Langenberg, 2004; Moorthy \& Arokiasamy, 2012).

Therefore the role of the internal environment is guided by a business owner is important to support the efforts of going green in the district of Aceh Tamiang. Business especially those aware of 'go green' have a positive impact for the moral of the employees. Employees who are the initiator of the environmental practices became more intense, this is resulted in the company's desire of fulfilling the employees dream of practicing business related to environmentally friendly (Viviers, 2009) 
Researchers saw the micro, small and medium-sized businesses in the district of Aceh Tamiang is still low with the activities on the environmentally friendly during the business management and is considered of not having the capability to support economic sustainable growth in the district of Aceh Tamiang. It is required to analyze how the role of the internal environment influence to empower the micro small and medium-sized business based on environmental management for 'go green' businesses to be able to support sustainable development for the district of Aceh Tamiang.

\section{Theory}

\subsection{Environmental management}

There are numerous tools for companies to manage the environment related to the process of running the business. Environmental management system is the plan of the management system, schedule, implement and monitor activities to improve the performance of the environment (Anthony, 2002). The practice of management development company environment inspired many of the evaluation of the implementation of the ISO 14001.

Companies that have implemented ISO 14001, have the impact of intangible him namely increasing the motivation work (because of security and safety is guaranteed), increase the confidence of employees policy management, Improve company image among employees and the community. (Hillary, 2000 and Purwanto, 2002). Environmental Management provides benefits both at the organizational level, including the following:

1. The protection of the physical environment

2. Form of sustainable culture in the organization

3. Instill moral values and mutual trust between elements of the organization

\subsection{Internal environment}

According to Purwanti and Fattah (2011), the internal environment is the workplace managers include company culture, production technology, organizational structure and physical facilities. According to Margaretta (2012), the internal environment of the company owned by the strength of the organization is controlled by the management. 
Hubeis and Najib (2014) holds that the internal environment is the environmental organizations that are in the organization usually has implications directly and specifically in the company. Thus the analysis of the internal environment includes resource analysis capability and competency possessed by the company

\subsection{Framework of research}

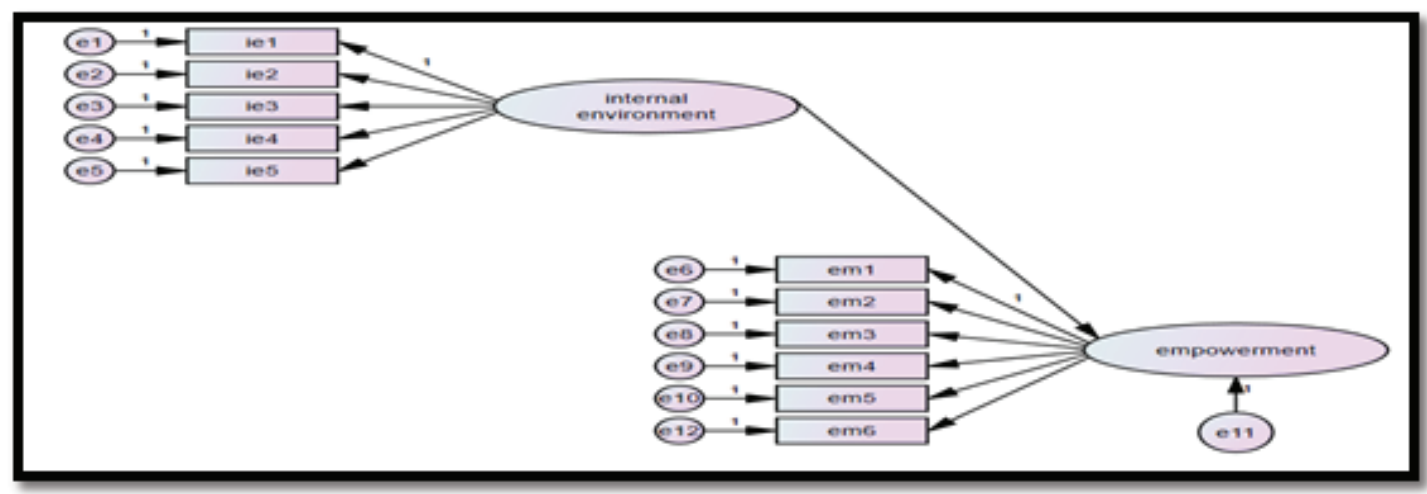

Figure 1: A framework of research. (Source: Data Processing, 2017).

\section{Hypothesis}

The hypothesis of this research is:

1. Internal environment MSMES have a significant influence on the empowerment of MSMES based on environmental management.

\section{Method}

This research using survey approach and it is research and development. The research population is 965 small businesses in the district of Aceh Tamiang, selected based on the business has the waste in the production process and business activities are done. Samples taken as much as 300 respondents to meet the criteria of the test samples of SEMs were held in the most fit for maximum likelihood analysis (Ghozali, 2005). Sampling techniques is random sampling based on data of MSMEs district of Aceh Tamiang. The source of data taken through the questionnaire and documentation. Data analysis techniques used to answer the hypothesis using descriptive statistics with the software SPSS and Structural Equation Modeling (SEM) with software Amos 


\section{Result}

\subsection{Descriptive statistics}

The district of Aceh Tamiang is also dominated by industrial business doers as much as $78 \%$ and the rest are the field of services about $17 \%$ and $5 \%$ is in manufacturing. Eighty-eight percent have limited access on the information regarding business construction using environmental management methods, while the remaining $12 \%$ stated that they have received information about the construction of environmental management based business but have minimum understanding therefore they do not apply the system in managing its business. Other Data show that there are $94 \%$ who stated that they do not follow the construction of the business based on environmental management and the remaining 6\% stated that never participate in the construction of environmental management based business.

Furthermore, the results of the survey showed that there are 66\% stating that business doers do not use environmental management system in managing household business and the remaining $34 \%$ use environmental management system in managing household business. However, in reality, the system they used is a simple in a form of awareness to keep the environment clean, have good waste management. Environmental Management System used is not based on the method given during the mentoring of business construction based on environmental management.

\subsection{Results of data processing}

The results of the data processing the role of some factors internal environment to empower small business community becomes an environmentally friendly can be seen on the full model that analyzed using structural equation modeling that assisted with AMOS following:

After the test results of full model structural equation modeling, it can be known the criteria of goodness of fit the model of this research based on the table of goodness of fit index following:

The test results showed the criteria model full model that is very fit, where all the feasibility criteria meet the standard model Goodness of Fit Index of the desired model to test the structural equation model in Table 1.

The results of hypothesis test, we can informed: 


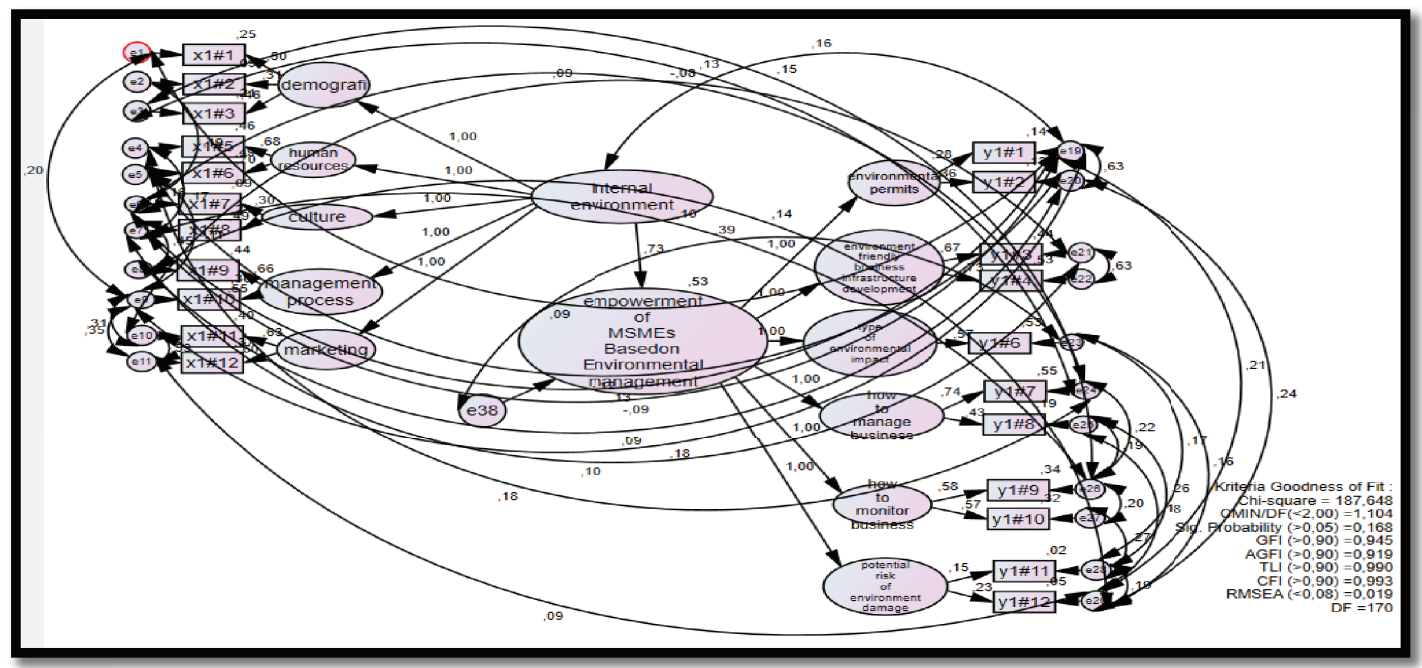

Figure 2: Full Model SEM. (Source: Data Processing, 2018).

TABLE 1: Goodness of Fit Index.

\begin{tabular}{l|c|c|c|c|} 
No. & Goodness of Fit Index & Cut-off Value & Hasil Analisis & Evaluation Model \\
\hline 1 & X2 $^{2}$ - Chi-square & Diharapkan kecil & 187.648 & Good fit \\
\hline 2 & Probability & $\geq 0.05$ & 0.168 & Good fit \\
\hline 3 & CMIN/DF & $<2.00$ & 1.104 & Good Fit \\
\hline 4 & RMSEA & $\leq 0.08$ & 0.019 & Good Fit \\
\hline 5 & GFI & $\geq 0.90$ & 0.945 & Good Fit \\
\hline 6 & AGFI & $\geq 0.90$ & 0.919 & Good Fit \\
\hline 7 & TLI & $\geq 0.90$ & 0.990 & Good Fit \\
\hline 8 & CFI & $\geq 0.90$ & 0.993 & Good Fit \\
\hline Source: Data Processing (2018). & & &
\end{tabular}

1. Internal environment have positive significant impact on the empowerment of small businesses based on environmental management with the value of $p$ (0.000) and value estimate (0.730).

2. Human resources consisting of employees and business doers able to significantly support the internal environment business doers to become a friendly business environment, with the value of $p$ (0.000) and value estimate (1.000).

3. The culture of business doers that is closely related to the culture of the district of Aceh Tamiang able to significantly support the internal environment business doers to become a friendly business environment, with the value of $p$ (0.000) and value estimate (1.000).

4. The management of sudha applied by business doers is able to significantly support the internal environment business doers to become an environmentally friendly business with the value of $p$ (0.000) and value estimate (1.000). 
5. Marketing methods that run business doers able to significantly support the internal environment business doers to become an environmentally friendly business with the value of $p(0.000)$ and value estimate (1.000).

6. Demographic factors business doers able to significantly support the internal environment pelau effort to be environmentally friendly business with the value of $p(0.000)$ and value estimate (1.000).

7. Environmental permissions are able to significantly support the empowerment of small businesses based on environmental management with the value of $p$ (0.000) and value estimate (1.000).

8. The factor of the infrastructure development environment-friendly business significantly capable to support the empowerment of small businesses based on environmental management with the value of $p(0.000)$ and value estimate (1.000).

9. The type of environmental impact caused by the small business community significantly capable to support the empowerment of small businesses based on environmental management with the value of $p$ (0.001) and value estimate (1.000)

10. How to manage businesses that used by business doers also significantly capable to support the empowerment of small businesses based on environmental management with the value of $p$ (0.000) and value estimate (1.000).

11. How to monitor the efforts that used the perpetrators of business to the factors that support the empowerment of small businesses based on environmental management with the value of $p$ (0.001) with the value estimate (1.000).

12. The potential risk of damage to the environment that appears as a result of running the business community of Aceh Tamiang is also able to significantly support the empowerment of small businesses based on environmental management with the value of $p(0.050)$ and value estimate (1.000).

\section{Discussion}

The research results prove that the internal environment of the SMMEs which includes human resource factors (employees and the business owner), culture, management, marketing and demographics (income, age, education) are capable of contributing 
significant influences toward small business empowerment based on environmental management. This means that the internal environment has a strong influence and a real impact on the empowerment program for environment-friendly business. Well management of the internal environment factors is effective in empowering a small business based on environmental management. On the other hand if the internal environment business is not well-managed, it is not effective in supporting the success of small business community empowerment to become a friendly business environment. All factors that build the internal environment of small business in the district of Aceh Tamiang namely human resources, demographic, culture, management, marketing are also known to be able to support the internal environment the perpetrators of the small businesses significantly.

The labor and business owner must be mentored for better creativity in producing products, able to cope with the technology developed to create innovation in producing an environmentally friendly product is surely part of the small business empowerment program based on environmental management. The existence of productive age manages to grasp information better and the income gained is able to meet the production process and this required to be mentored according to the business program for environment-friendly product.

The results of this research are supported by Sutrisno and Lestari (2006), then Afifah (2012) mentioned that one of the biggest challenges for the development of the small business community is the human resources employment with limited knowledge and skills so that they could not work optimally to meet the business goals. The empowerment of employees is needed for the business to be able to run the environmentfriendly business, using good environmental management. Especially now where the government is running the environmental management which was inspired by the evaluation of the implementation of ISO 14001 which in practice requires the energy of human resources and smart business continuity in skill. Hillary (2000) and Purwanto (2002) stated that the company implementing environmental management and running the business according to ISO 14001 well, will get a positive response from employees and the increase on the motivation of work due to the awareness regarding safety and security of work, trust employees to companies, business management become better and increase the image of a business for better employees and community. 
Management factors also became one of the elements of the internal environment that supports the empowerment of the business based on environmental management becoming environmentally friendly business. Procedures for managing the management become the most powerful factor that most powerful role to influence the success of business empowerment based on environmental management in the district of Aceh Tamiang. This requires the involvement of all employees and the business owners to manage their business management in accordance to the management of the environment and become a friendly business environment. Marketing techniques applied by business doers is also a factor that plays an important role to support business environment friendly through the empowerment of the business based on environmental management. business doers in marketing its products must support the salvation of the environment namely business doers using the environment-friendly marketing techniques such as to take advantage of the media in the promotion of environmentally friendly that does not cause a waste, take advantage of the promotional technology that can also get the information market opportunities and campaigns on environmental awareness. This requires a good education support from the government in the construction of the small business doers in the district of Aceh Tamiang.

All internal environmental factors as perpetrators or supporters of the implementation of MSMES empowerment program based on environmental management that later will be able to manage the business becoming an environmentally friendly business in accordance with the purpose of the government related to the ISO 14001 expected the entire production process or the business inception should consider the impact on the environment. The results of this research is supported by Amir $\&$ Rachmawati, (2003) That mentions that the internal environment consists of capital, employment, raw materials, production equipment and marketing hurdle for small business empowerment in Banyumas, so it needed the right empowerment model for the training of labor to maximize the internal factors in the production process and the management is the technology innovations and waste water treatment will be added value and benefits for the company. Braun (2016), In his research mentions that women are far more intuition of environmental issues that become the impact from the continuation of a business. The women become business doers more forthcoming with the environment so that running the business with a number of innovations environmentally friendly, run the business management with environmental management methods, producing an environmentally friendly product, integrating internal and external motivation to run the business environment friendly (Taylor and Walley, 2004). 
All factors empowerment builders based small business management is known able to significantly support empowerment role-based business environment management. As one of the internal factors namely human resources acting as the business must be running and monitoring the business oriented on the environment, trying to prevent the damage of environment, with the support of infrastructure and environment-friendly to the potential risk of environmental damage can be avoided (Moorthy \& Arokiasamy, 2012)

\section{Conclusion}

Internal environment significantly effect on the construction of small businesses using the concept of the environmental management, helping the achievement of the concept of 'go green' business in the district of Aceh Tamiang. Human resources that consist of the entrepreneurs and the employees have an important role because their attitudes, behavior and opinion determine how to manage business, monitoring business in maintaining environmental sustainability. In addition the construction is also related to the behavior of the efforts of perpetrators to take advantage of the technology, to create an environment-friendly innovation product and to take advantage of the facilities and infrastructure will not damage the sustainability of the environment because it's an environment-friendly business.

\section{Acknowledgment}

The authors are very grateful to their promoter and mentor for helping then in completing this research. If there is an error and confusion in this research, it is the responsibility of the authors. The authors declare that the findings in this research are also their own opinions and do not become the opinions of the public.

\section{References}

[1] Afifah, R. Z. (2012). Analysis of Credit and Capital Assistance for Groups Elaku Micro Small Medium Enterprises and Cooperatives by the Semarang City (a case study of KPUM Village In Pekunden Subdistrict, Semarang). Semarang: UNDIP. Retrieved from http://eprints.undip.ac.id/35806/1/AFIFAH.pdf

[2] Amir and Rachmawati, E. (2003). Study the potential of small industries in the village left behind in order to empowerment of small entrepreneurs in Banyumas District 
1.

[3] Bank Indonesia. (2012). Review the Readiness of the Environment-friendly Small Medium Enterprises in Gaining Access to Financing.

[4] Braun, P. (2016). Going Green: Women Entrepreneurs and the Environment. International Journal of Gender and Entrepreneurship, September 2010, pp. 1-9.

[5] Creech, H., Paas, L., Gabriel, G. H., et al. (2014). Development in Practice Small-scale Social-environmental Enterprises in the Green Economy: Supporting Grassroots Innovation. Development in Practice, vol. 24, no. 3, pp. 366-378.

[6] Ghozali, I. (2005). The Application of Multivariate Analysis with SPSS Program. Semarang: Universitas Diponegoro Press.

[7] Hillary, R. (2000). Environmental management standards: What Do the smes think?, in Sheldon Christopher (ed.) ISO 14001 and Beyond, Pp. 333-358. Sheffield, UK: Greenleaf Publishing.

[8] Indarti, N. and Langenberg, M. (2004). Factors affecting business success among SMEs: Empirical evidences From Indonesia, in Second Bi-annual European Summer, pp. 1-15.

[9] Indris, S. and Primiana, I. (2015). Internal and External Environment Analysis on the Performance of Small and Medium Industries (SMEs) in Indonesia. International Journal Of Scientific \& Technology Research, vol. 4, no. 4, pp. 188-196.

[10] Moorthy, M. K. and Arokiasamy, D. L. (2012). Drivers for Malaysian SMEs to go green. International Journal of Academic Research in Business and Social Sciences, vol. 2, no. 9, pp. 74-86.

[11] Purwanto, A. T. (2002). Analysis of the Influence of the Implementation of the ISO 14001 Environmental Performance Indicators Against Quantitative and Qualitative Use ISO 14031 EPE Model Development. Thesis, Bandung Institute of Technology, Indonesia.

[12] Sutrisno, J. and Lestari, S. (2006). Study of Micro-Indonesia. Journal for the Study of Cooperatives and SMEs, vol. 2, no. 1, pp. 13-25.

[13] Viviers, S. (2009). Going Green囚: An SMME Perspective. SAJESBM NS, vol. 2, no. 1, pp. 30-49. 